\title{
ACCOUNTING AND ENTERPRISE RISK MANAGEMENT
}

\author{
Elżbieta Klamut* $\odot$ http://orcid.org/0000-0002-4304-0665
}

Knowledge rests not upon truth alone, but upon error also.

Carl Gustav Jung

\begin{abstract}
Background. Regardless of their size, enterprises to achieve their goals should implement risk management in their management processes. One of the tools that can help to control this management is the accounting system. Entrepreneurs in the SME sector are reluctant to run full records of their business activities. Is that right?

Research aims. The purpose of the article is to identify the areas of activity of an enterprise in which accounting will fulfill its role as a risk minimization tool or as a risk signalling device. For the purposes of this study, it was hypothesized that an appropriately structured accounting system supported by additional information would allow for the minimization of the risks (adverse effects) of many economic activities.
\end{abstract}

Methodology. A pilot study examining whether there is a need for deeper research into broader accounting involvement in the risk management process in SMEs. In order to realize the research problem that was established, the analysis of literature, the author's experience and the research in a group of small enterprises have been used.

Key findings. Small enterprises do not attach importance to keeping full records (accounting), they do not perceive it as a source of risk information, as they do not notice nor manage the risk. They treat it as something superfluous, costly, but not very useful, apart from the records for tax settlement purposes. It would be necessary to educate entrepreneurs and the people running their books on the use of accounting in risk management. Organizations like PARP (the Polish Agency for Enterprise Development) can do this. With the EU funding, they should organize free of charge risk management training opportunities for SME entrepreneurs.

Keywords: risk management, accounting.

JEL Codes: G32

* Faculty of Management and Safety Sciences, University of Social Sciences in Lodz, Sienkiewicza 9, 90-113 Łódź, Poland. E-mail: eklamut@san.edu.pl 


\section{INTRODUCTION}

Not so long ago many small and medium-sized entrepreneurs in Poland treated the accounting a bit lightly. It was treated as a necessary evil by them. The management of an enterprise was rather intuitive than based on any analysis. The centrally managed economy did not enforce such a necessity. Along with the free market economy, more and more private property appeared, thus taking care of maximum profits has increased. Today, even small enterprises are using different kinds of analysis, research, as they want to improve their competitiveness. Acting in so variable as the present conditions carries a significant risk, particularly threatening those entities that do not control it. Depending on the type and area of action activity, companies must manage a lower or greater number of encountered risks. They can use many risk management tools; yet the possibilities for their implementation remain a matter of their decision. The risks alter along with the changing economic or political environment and enterprises must be appropriately prepared for these changes. To minimize the adverse effects of the risk, they must be ahead of its occurrence and apply appropriate tools in advance.

Usually, micro and small enterprises do not implement risk management systems. The small scale of their business activities limits the possibility of occurrence of certain risks, but they should nevertheless monitor and control the risks.

Is accounting a tool that can help manage the risk? What role does it have to play? Should it be only a system of activity records, or can it indicate some of the areas where risks may occur? Or perhaps it is a system that instead of minimizing, generates risks? These are the questions that the author seeks to find an answer in this study. The search for solutions to these problems can be facilitated by putting forward a hypothesis that the accounting system appropriately structured and supported by additional information can help actions minimizing the risk of business. 


\section{THEORETICAL BACKGROUND}

Accounting in organizations. The legislature diversified the system of business records in Poland depending on the size, type of activity or decision of the entrepreneur. Flat-rate forms of taxation of natural persons' activities may use simplified means of recording in the form of registration of income, fixed assets, pay slips, etc. In the case of a tax card, in principle there is no need for records, and in the case of a lump sum tax on registered incomes - only the records mentioned above. More detailed is the accounting of the activity in the form of the tax ledger of revenues and expenses. It fulfills the requirements for determining personal income tax of natural persons, hence the necessity to record both the revenue and the cost of obtaining this revenue. Natural persons (their entities) operating on a larger scale and legal persons shall be required to record in full their activities, that is to say, any economic operation. Such records allow for an overall overview of the company's resources and, above all, their control. These records are based on the provisions of the Accounting Act.

Accounting is a system that mainly measures all events and operations occurring in a business, but it is also a system of presentation of these processes. Accounting as: "the theory of economic measurement (value measurement) and as a system of this measurement in companies and institutions" defines E. Burzym (1993, p. 7). He also describes accounting as: "a universal, subjective information and control system" (Burzym, 1980, p. 13).

Each company to obtain the desired information necessary in the management process introduces an additional accounting element, the so-called management accounting, which is an information system based on internal regulations and used only for the needs of this organization. It aims to detect irregularities in the functioning of the company (information and control function), including errors in decisions, abuses, mismanagement and support of decision-making processes. The operational management accounting corrects the undesirable effects of the actions on an ongoing basis while the strategic accounting plans future changes in the organization based on analysis, cost accounts, etc. in order to support achieving the objectives of the company. 
The accounting is closely linked to internal control, internal audit and auditing of financial statements, which are instruments for maintaining the proper functioning of the company, as well as identification of risks occurring in organizations.

Although accounting is a risk-management tool, it also generates some risks as an information system. These are the most common: the risk of erroneous records, the risk of reliability of financial statements, tax risk, the risk of inadequacy of registration computer programs to the specifics of the business, the risk of human resources and many others. Examples of such risks and the inducing agents are given in table 1 .

Table 1. Risk areas in the accounting system

\begin{tabular}{|c|c|}
\hline Type of risk & Description \\
\hline $\begin{array}{l}\text { Documen- } \\
\text { tation } \\
\text { workflow }\end{array}$ & $\begin{array}{l}\text { - delays in providing the documentation for the accounting } \\
\text { - unduly long period of document approval (substantive, formal and } \\
\text { accounting checks) } \\
\text { - incorrect issuance of accounting records } \\
\text { - incorrect description of accounting records in terms of substance - incon- } \\
\text { sistent with tax laws }\end{array}$ \\
\hline $\begin{array}{l}\text { Information } \\
\text { systems }\end{array}$ & $\begin{array}{l}\text { - maladjustment of programs to the specifics of business activities } \\
\text { - frequent errors in data transmission } \\
\text { - too long registration data entry process } \\
\text { - incorrect assumptions in cost account clearance (inadequate analytics) } \\
\text { - long waiting period for clearing accounting errors } \\
\text { - authorization issues }\end{array}$ \\
\hline Registration & $\begin{array}{l}\text { - irregularities and errors in endorsement or registration of economic } \\
\text { operations } \\
\text { - complex and excessive account analytics } \\
\text { - possibility of errors between accounting software modules } \\
\text { - wrong assignment of ledger account to invoice index }\end{array}$ \\
\hline $\begin{array}{l}\text { Human } \\
\text { resources }\end{array}$ & $\begin{array}{l}\text { - lack of professional development trainings } \\
\text { - inappropriate motivation to work or personal development } \\
\text { - inappropriate substitution system } \\
\text { - lack of the incentive system }\end{array}$ \\
\hline $\begin{array}{l}\text { Tax } \\
\text { settlements }\end{array}$ & $\begin{array}{l}\text { - possibility of errors in the application of tax laws } \\
\text { - misinterpretation of tax laws } \\
\text { - organizational problems related to frequent audits of tax authorities }\end{array}$ \\
\hline $\begin{array}{l}\text { Recovery } \\
\text { (Vindication) }\end{array}$ & $\begin{array}{l}\text { - unsuitable system of monitoring and prompting receivables } \\
\text { - delays in receivables collection }\end{array}$ \\
\hline Inventory & $\begin{array}{l}\text { - lack of attribution of liability for company property } \\
\text { - too long inventory differences settlement period } \\
\text { - significant fragmentation of liability for company property }\end{array}$ \\
\hline Legal & $\begin{array}{l}\text { - improper actions not complying with applicable accounting laws and } \\
\text { tax law } \\
\text { - poorly updated knowledge of current balance and tax laws }\end{array}$ \\
\hline
\end{tabular}


Table 1. cont.

\begin{tabular}{|l|l|}
\hline Type of risk & \multicolumn{1}{c|}{ Description } \\
\hline Valuation & $\begin{array}{l}\text { - problems with the valuation of assets and liabilities } \\
- \text { inadequate methods for the valuation of assets for lease or for sale } \\
- \text { incorrect application of valuation due to foreign exchange rates }\end{array}$ \\
\hline Analytical & $\begin{array}{l}- \text { erroneous assumptions in reporting for decision-making purposes } \\
- \text { wrongly designated objectives of financial, and management analysis } \\
\text { of wrong parameters) } \\
- \text { too long reporting times } \\
- \text { selection of non-essential data for the taken decision }\end{array}$ \\
\hline
\end{tabular}

Source: own study.

Almost any of these risks listed above can be eliminated through an appropriate accounting organization.

The reliability and credibility of information from the accounting system is a necessary factor that allows for an adequate analysis of the financial situation of the entity and provides a basis for risk assessment. In the case of simplified forms of registration of activities, access to the appropriate information necessary for management processes is considerably limited and only allows for residual analysis. Without additional records held solely for the purposes of the company, it is not possible to analyze in depth the financial situation and to monitor risks. Unfortunately, the use of creative accounting in the financial books and reporting in the positive and negative sense distorts the actual image of the entity's situation, and it misleads managers, investors, banks, etc.

\section{Risk management in the SME sector}

The key objective of each enterprise is to achieve maximum effect of its activities (gain profit, maximize its value). However, an ideal environment that would allow the company to operate freely does not exist. There is always some uncertainty and a risk of not achieving the planned effects and goals. The risk is a permanent part of any business and covers almost all areas of the company, i.e. resources: material, financial, intangible, human, legal and also the responsibility for decisions in the management process. It exists because of the unpredictability of the future event. The effects of such an event have a financial impact. The consequences of the risk can affect the success 
or failure of the business. The effects of the risk may be negative, but also positive.

Micro, small and medium-sized enterprises are generally more vulnerable to internal and external risks than the large ones, and risk factors are different in nature, and what's more, there is a different probability of their occurrence. The company management can use the following strategies:

- $\quad$ avoidance or restriction of the risk - reduction of the possibility of damages, preventive actions to minimize negative effects of the risk,

- retention of the risk - maintenance of financial reserves in the suitable amounts to cover damage caused by the risk. This means the level of acceptable risk, monitoring and evaluation of that level, as well as the self-financing of the risk,

- risk transfer - transferring part of the risk to specialized entities (outsourcing, insurance).

Risk management today are actions aimed at reducing the degree of risk impact on the operation of the organization. The most common are actions that minimize the impact and effects of risks or their prevention. The objective of risk management is to provide maximum sustainable benefits.

According to Damian Gajda, taking actions to avoid risk:

(...) does not imply an optimal solution from the point of view of the company. In some situations, it is contradictory to entrepreneurship, which includes risk-taking. Whereas the transfer of risk financing involves offsetting losses by another entity through properly constructed contracts with counterparties, the use of outsourcing, hedging transactions and insurance (Gajda, 2014, p. 212).

Risk management may help SME managers to identify significant risks that could jeopardize the success or existence of the company in time to efficiently cope with them (Brustbauer, 2014). However, many SMEs do not - or not adequately - apply risk management practices, mostly because they cannot afford to rededicate resources due to their constraints (Marcelino-Sádaba et al., 2014). This fact is somewhat regrettable because SMEs make up a large share of firms in developing countries (Lavia Lopez \& Hiebl, 2014), and risk management may be a key factor in increasing their ability to survive, which in turn may also have an important impact on the economies of developing countries. 
Based on a survey conducted by Kim and Vonortas (2014) among 4000 enterprises in the SME sector in Europe, it can be said that the better educated owners of the companies in this sector are, the more likely they are to take appropriate strategic action to reduce the risk of business.

Many scientific studies present different sources of risk in the small and medium-sized enterprises sector. The most common ones are presented in table 2 .

Table 2. Risk sources in the small and medium-sized enterprises sector

\begin{tabular}{|c|c|}
\hline Type of factor & Specification \\
\hline External factors & $\begin{array}{l}\text { - globalization } \\
\text { - fluctuation of raw material prices } \\
\text { - increasing competition } \\
\text { - economic slowdown } \\
\text { - changes in the legal/regulatory environment } \\
\text { - natural disasters, extreme weather conditions }\end{array}$ \\
\hline Enterprise management & $\begin{array}{l}\text { - loss of reputation } \\
\text { - social responsibility } \\
\text { - lack of innovation }\end{array}$ \\
\hline Financial factors & $\begin{array}{l}\text { - loss of liquidity/liquidity risk } \\
\text { - capital availability/structure of capital } \\
\text { - fluctuations in exchange rates } \\
\text { - contractors - commercial receivables } \\
\text { - fluctuations in interest rates }\end{array}$ \\
\hline Operational factors & $\begin{array}{l}\text { - disruption/interruption in the supply chain } \\
\text { - downtime (business interruption) } \\
\text { - product withdrawal from the market } \\
\text { - impact on the environment }\end{array}$ \\
\hline IT risk & $\begin{array}{l}\text { - loss of data } \\
\text { - technological failure }\end{array}$ \\
\hline Human resources & $\begin{array}{l}\text { - employee absenteeism } \\
\text { - loss of talented workers } \\
\text { - accidents at work } \\
\text { - shrinking labour market }\end{array}$ \\
\hline Crime/security & $\begin{array}{l}\text { - employee dishonesty } \\
\text { - theft } \\
\text { - economic espionage } \\
\text { - defraudation }\end{array}$ \\
\hline
\end{tabular}

Source: own study based on: Słabosz \& Ziomko, 2009, p. 17.

Another selection of risk factors in the small and medium-sized enterprises sector indicates factors such as loss of liquidity, upturn or slowdown in the economy, fluctuations in raw material prices, changes in legislation, loss of key employees, exchange rate fluctuations, 
reputational losses, business partners - trade receivables, and also the interruption of business activity.

Looking at companies in the SME sector, unfortunately, it is noted that most of them do not have any strategies developed, nor do they implement any standardized risk management systems, and decisions take at an ad hoc approach. It is different in large companies; although they do not always appreciate the role of risk management systems, nevertheless their qualitative level of risk management is much higher. These entities gradually try to attach importance to the use of professional risk management tools. It is worth noting that the activities in the SME sector are often small, hence the use of an advanced risk management system is not economically justified. Larger economic operators are usually financially stable and have adequate funding for IT systems, training costs, or additional human resources. Young entrepreneurs are most likely to know about risks, how to identify and manage them, but they have difficulty in applying their knowledge in practice. In addition, the barrier to the use of risk management is that there is no possibility of distinguishing the relevant units from the organization structure. This means that these small entities do not employ people who would deal only with risk identification and risk management. Another reason for the lack of suitable people involved in risk management is the financial barrier. Small entities are not able to keep such an employee by providing him or her not only with adequate remuneration but they also cannot provide adequate risk management tools. And yet appropriate identification of reasons for e.g. bankruptcy, may significantly reduce the risk. However, they can limit risks by assigning risk management responsibilities to key workers who are best acquainted and understand the nature of the entity's activities. The SME sector means micro, small and medium-sized enterprises; these micro-entities do not have extensive business, so they are less vulnerable to risks, but the larger ones should use the services of external risk management professionals or develop an appropriate strategy based on different variants according to the changing situation in the environment.

The information itself on the risk is not sufficient, so many scientists and practitioners believe that, for example, the financial statements should be accompanied by a risk report containing: identification and prioritization of risks, description of measures taken in the framework of 
risk management, defining criteria for measuring this risk (Karmańska, 2008, p. 390). The stages of this report are presented in table 3.

Table 3. Stages of the risk report preparation

\begin{tabular}{|c|c|c|}
\hline Risk report & Actions & $\begin{array}{l}\text { Required sources } \\
\text { (Methods used) }\end{array}$ \\
\hline $\begin{array}{l}\text { Stage } 1 \\
\text { Identification and } \\
\text { prioritization of key } \\
\text { risks }\end{array}$ & $\begin{array}{l}\text { Identification of all key risks } \\
\text { based on: } \\
\text { - likelihood } \\
\text { - significance }\end{array}$ & $\begin{array}{l}\text { - overview of the company's tasks } \\
\text { and strategies, } \\
\text { - broad discussion inside the entity, } \\
\text { - reference to the general list of } \\
\text { risks, } \\
\text { - determination of importance, e.g. } \\
\text { using a risk map }\end{array}$ \\
\hline $\begin{array}{l}\text { Stage } 2 \\
\text { Description of } \\
\text { actions taken to } \\
\text { manage any risk }\end{array}$ & $\begin{array}{l}\text { Approval of actions against } \\
\text { identified risks: } \\
\text { - transfer of risk } \\
\text { - acceptance of risk } \\
\text { - risk sharing } \\
\text { - introduction of controls }\end{array}$ & $\begin{array}{l}\text { - consideration of outsourcing } \\
\text { - assessment of strategic alliances/ } \\
\text { joint ventures } \\
\text { - taking into account the use of } \\
\text { derivative instruments } \\
\text { - comparison of checks with best } \\
\text { practice lists } \\
\text { - overview of insurance policies }\end{array}$ \\
\hline $\begin{array}{l}\text { Stage } 3 \\
\text { Identification of risk } \\
\text { measurement }\end{array}$ & $\begin{array}{l}\text { explanation of the risk mea- } \\
\text { surement and monitoring } \\
\text { process }\end{array}$ & $\begin{array}{l}\text { - information from accounting } \\
\text { - non-financial performance meters } \\
\text { - market research } \\
\text { - sensitivity analysis } \\
\text { - value at risk (VAR) }\end{array}$ \\
\hline $\begin{array}{l}\text { Stage } 4 \\
\text { Final preparation } \\
\text { of the report for } \\
\text { publication }\end{array}$ & $\begin{array}{l}\text { referencing other report } \\
\text { items and confirming the } \\
\text { absence of sensitive commer- } \\
\text { cial and legal issues }\end{array}$ & $\begin{array}{l}\text { - formal consideration by the } \\
\text { management board and the audit } \\
\text { committee }\end{array}$ \\
\hline
\end{tabular}

Source: own study based on: Financial..., 1997, p. 11.

Studies of risk areas and types of risk in the SME sector, in particular in micro and small economic units (Korombel, 2011, p. 235), mainly indicate operational and market risks, as well as human capital, finance and law regulations risks (Figure 1).

Environment, a greater awareness amongst entrepreneurs are changing the business approach to risk. Further research in this area in the SME sector shows that external and financial factors create the greatest threat to the activities of these organizations. The risk factors associated with the management of the company, human resources, crime and security, as well as operational and technological factors (Kokot-Stępień, 2015, p. 540), play a lesser role.

In comparison, it is worth to present studies on changes in risk factors globally and in Europe (table 4). 

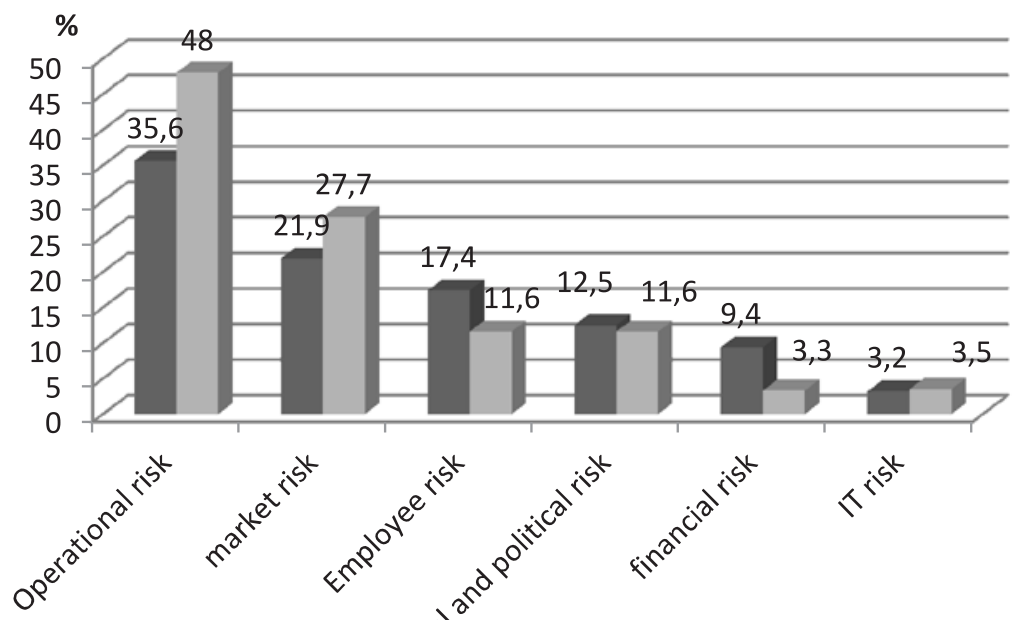

Figure 1. Key risks for small and medium enterprises in Poland

Source: own study based on: Korombel, 2011, p. 235.

Table 4. Key risks for small and medium enterprises / statistics in \% and ranks. All countries

\begin{tabular}{|l|r|r|r|r|}
\hline \multirow{2}{*}{ Risk } & \multicolumn{2}{c|}{ Global } & \multicolumn{2}{c|}{ Europe } \\
\cline { 2 - 5 } & $\mathbf{2 0 1 5}$ & $\mathbf{2 0 1 3}$ & $\mathbf{2 0 1 5}$ & $\mathbf{2 0 1 3}$ \\
\hline Fire & 8.5 & 6.7 & 6.8 & 4.7 \\
\hline Theft & 12.8 & 19.1 & 12.3 & 16.4 \\
\hline Cybercrime (e.g. computer hacking, online fraud etc) & 7.9 & 4.2 & 6.8 & 4.1 \\
\hline Technological vulnerabilities / IT failures & 8.0 & 6.3 & 6.6 & 6.3 \\
\hline Transport / Damage to company vehicle & 9.6 & 7.6 & 8.3 & 7.0 \\
\hline Customers or employees health and safety & 11.4 & 11.0 & 13.5 & 12.9 \\
\hline Riots and malicious damage & 4.0 & 5.3 & 1.7 & 4.3 \\
\hline Reputation damage (i.e. negative media coverage) & 13.4 & 7.5 & 13.7 & 7.0 \\
\hline Failure of partners and suppliers & 9.8 & 12.8 & 7.9 & 11.7 \\
\hline Natural catastrophes / Unpredictable Weather & 7.4 & 7.5 & 4.6 & 8.3 \\
\hline Lack of consumer demand / Overstocking & 32.2 & 23.7 & 36.9 & 27.8 \\
\hline Legal and fiscal problems & 14.3 & 11.2 & 15.1 & 10.2 \\
\hline Corruption & 5.8 & 5.7 & 4.6 & 3.5 \\
\hline $\begin{array}{l}\text { High competition / Dumping prices impacting sales } \\
\text { margins }\end{array}$ & 34.4 & 36.1 & 36.4 & 35.0 \\
\hline I don't think there are any risks for my business & 10.4 & 0.0 & 9.6 & 0.0 \\
\hline
\end{tabular}

Source: own study based on: Key Risks..., 2015, p. 9, 12. 
According to the above research results, most risk factors are perceived similarly by entrepreneurs in Europe (highly developed countries [7]) and globally (USA, Latin America [2], APAC [2], Middle East \& Africa [3]).

\section{Accounting and selected risks of the company}

The accounting system provides information on the activities of an enterprise for the purposes of decision-making processes. The most common way to determine the likelihood of a risk occurrence is to analyze the financial statements, and in this data the determination of anomalies, deviations from the established plans. Particular attention shall be paid to those risks whose effects may be severe for the operator. The risk-identification capabilities of the individual elements of the financial statements are presented in table 5 .

Table 5. Risk types identified through financial reports

\begin{tabular}{|l|l|}
\hline \multicolumn{1}{|c|}{ Report item } & \multicolumn{1}{c|}{ Type of risk } \\
\hline Balance sheets & $\begin{array}{l}\text { - the risk arising from the structure of the assets or liabilities, } \\
\text { - the risk arising from the structure of fixed assets } \\
\text { - the risk arising from the structure of the current assets } \\
\text { - the risk arising from equity structure } \\
\text { - the risk arising from the structure of third party capital } \\
\text { - the liquidity risk } \\
\text { - the risk of price changes } \\
\text { - the operational risk } \\
\text { - the risk of profitability in the context of the liabilities structure } \\
\text { - the currency risk } \\
\text { - the interest rate risk }\end{array}$ \\
\hline $\begin{array}{l}\text { Profit and loss } \\
\text { account }\end{array}$ & $\begin{array}{l}\text { - the risk of volatility of the financial result } \\
\text { - the risk of measuring results } \\
\text { - the risks associated with overall business activities }\end{array}$ \\
\hline $\begin{array}{l}\text { Cash flow } \\
\text { statement }\end{array}$ & $\begin{array}{l}\text { - the risk of mistakes in the management of sources of financing } \\
\text { - the risk of loss of payment ability } \\
\text { - the risk of operating activities } \\
\text { - the risk of bankruptcy }\end{array}$ \\
\hline $\begin{array}{l}\text { Statement of } \\
\text { changes in equity }\end{array}$ & $\begin{array}{l}\text { - the risk of the owner's conservative attitude } \\
\text { - the risk of an expansive dividend policy }\end{array}$ \\
\hline
\end{tabular}

Source: own study based on: Karmańska, 2008, pp. 440-475.

Based on the analysis of revenues and costs, it is possible to isolate the risk factors for the whole business, A. Karmańska (2008, p. 460) divided them into 3 groups respectively (table 6). 
Table 6. Risk factors identified on the basis of income and costs of the entity

\begin{tabular}{|c|c|}
\hline Type of risk & Risk factors \\
\hline $\begin{array}{l}\text { The risk associated } \\
\text { with overall busi- } \\
\text { ness activities }\end{array}$ & $\begin{array}{l}\text { These are factors: } \\
\text { - resulting from the choice of the legal form of the business } \\
\text { activity } \\
\text { - related to the adopted concept of business management } \\
\text { - related to the adopted concept of human capital management } \\
\text { - related to the balance sheet and fiscal policy } \\
\text { - related to the organization of the accounting system } \\
\text { - related to the organization and functioning of the control and } \\
\text { internal audit system } \\
\text { - related to the organization of the budgeting and controlling } \\
\text { system } \\
\text { - related to the adopted concept of entity development }\end{array}$ \\
\hline $\begin{array}{l}\text { The risk associated } \\
\text { with operational } \\
\text { activities }\end{array}$ & $\begin{array}{l}\text { These are factors related to: } \\
\text { - adopted strategy and marketing policy } \\
\text { - adopted methods of creation and maintenance of tangible eco- } \\
\text { nomic potential } \\
\text { - organization of operational tasks execution } \\
\text { - adopted organization of procurement and sales logistics } \\
\text { - management of operational assets and liabilities }\end{array}$ \\
\hline $\begin{array}{l}\text { The risk related to } \\
\text { financial and } \\
\text { investment } \\
\text { activities }\end{array}$ & $\begin{array}{l}\text { These are factors related to: } \\
\text { - financial asset management strategy } \\
\text { - prediction policy for the effectiveness and evaluation of invest- } \\
\text { ment projects } \\
\text { - adopted strategy for acquiring equity and using third party } \\
\text { sources of finance. }\end{array}$ \\
\hline
\end{tabular}

Source: own study based on: Karmańska, 2008, p. 460.

Unfortunately, it should be noted that without insight into the internal accounting system, the user of information from the financial statements can only very generally identify the factors of risk that may, but may not occur in reality. For example, a balance sheet analysis allows only for identification of those balance categories which are particularly exposed to risk (table 7).

The presentation of the economic risk in financial reporting, in its individual elements, unfortunately has its limitations. Not all of the risks without additional analysis or reporting are possible to determine. According to A. Karmańska (2008, p. 476), information gaps occur in the presentation of credit risk, liquidity risk or market risk. The lack of sufficient information in the reports should be complemented by appropriate additional sets of estimated risks on the means of its creation, valuation, etc. (see table 3). 
Table 7. Examples of specific risks and where to identify them in the balance sheet

\begin{tabular}{|c|c|c|c|c|}
\hline $\begin{array}{l}\text { Balance sheet items } \\
\text { Types of risks }\end{array}$ & Fixed assets & $\begin{array}{l}\text { Current } \\
\text { assets }\end{array}$ & $\begin{array}{l}\text { Third party } \\
\text { capital }\end{array}$ & Equity \\
\hline \multirow{2}{*}{ Operational risk } & \multicolumn{2}{|l|}{$\begin{array}{l}\text { Fixed assets } \\
\text { Current assets }\end{array}$} & & \\
\hline & \multicolumn{2}{|l|}{$\begin{array}{l}\text { Operating assets } \\
\text { Current assets }\end{array}$} & & \\
\hline \multirow{2}{*}{ Liquidity risk } & \multicolumn{2}{|l|}{$\begin{array}{l}\text { Fixed assets } \\
\text { Current assets }\end{array}$} & & \\
\hline & & \multicolumn{2}{|c|}{$\begin{array}{l}\text { Current assets } \\
\text { Short-term liabilities }\end{array}$} & \\
\hline \multirow{2}{*}{ Risk of profitability } & & & & Equity \\
\hline & \multicolumn{2}{|l|}{ Assets } & & Net profit \\
\hline Market risk & & & & \\
\hline $\begin{array}{l}\text { Risk of price } \\
\text { changes }\end{array}$ & \multicolumn{4}{|c|}{$\begin{array}{l}\text { Assets } \\
\text { Revaluation reserve } \\
\text { Liabilities }\end{array}$} \\
\hline Currency risk & \multicolumn{3}{|c|}{$\begin{array}{l}\text { Fixed assets under construction } \\
\text { Receivables } \\
\text { Investments } \\
\text { Liabilities }\end{array}$} & \\
\hline Interest rate risk & \multicolumn{3}{|c|}{$\begin{array}{l}\text { Fixed assets under construction } \\
\text { Receivables } \\
\text { Investments } \\
\text { Liabilities }\end{array}$} & \\
\hline
\end{tabular}

Source: own study based on: Karmańska, 2008, p. 448.

\section{METHODS}

\section{Selected risk minimization methods based on accounting.} When examining risks in the small and medium-sized enterprises sector, the research of key risks in this sector should be explored. The most common and threatening risks in the SME sector are the risks indicated in Table 8, in which there are also added for comparison risks in the large enterprises sector.

These studies show that the types of risks in both sectors are different. However, some of them occur regardless of the size of the company. These include: loss of liquidity, contractors - commercial receivables, changes in legal regulations, etc.

In this study, it is not possible to provide detailed characteristics of all risks, hence only a few of the following have been selected. 
Table 8. Key risks associated with doing business

\begin{tabular}{|l|l|}
\hline \multicolumn{1}{|c|}{ SME sector risk ranking } & \multicolumn{1}{|c|}{ Risk ranking of large enterprises } \\
\hline 1. Growing competition & 1. Economic slowdown \\
2. Loss of liquidity & 2. Growing competition \\
3. Loss of reputation & 3. Cash flow / liquidity risk \\
4. Contractors - commercial receivables & 4. Contractors - commercial receivables \\
5. Economic slowdown & 5. Changes in the legal and regulatory \\
6. Loss of key employees & environment \\
7. Raw materials price fluctuations & 6. Exchange rate fluctuations \\
8. Business interruption & 7. Raw materials price fluctuations \\
9. Amendments to the legislation & 8. Technological failure \\
10. Exchange rate fluctuations & 9. Employee dishonesty \\
& 10. Liability / claims \\
\hline
\end{tabular}

Source: own study based on: Przywecki et al., 2013, pp. 32-33.

The risk of accounting (business records) and tax settlements (tax risk) can be minimized by using finance and accounting outsourcing, i.e. the commissioning of accounting books to specialized entities, such as accountancy offices or consulting companies. The separation of accounting function from the organization structure and transfer it to the relevant external entity allows for transferring part of the risk to another entity. So there are no risk factors such as lack of a qualified team, improper adaptation of IT programs to the specifics of the business or information needs, poor organization of the accounting system, the erroneous interpretation of tax laws etc.

The transfer of risk does not imply a complete elimination of the risk, since the risk minimization depends on the quality of the accountancy offices services, bearing in mind that the contractor is required to be covered by civil liability insurance for committed errors in service provision, and this guarantees the minimization of the risk effects. When working on outsourcing, it is appropriate to ensure that the contractor has a high value insurance policy.

The accounting system may affect the reduction of the liquidity risk by providing appropriate information for the management of receivables as well as the development and ongoing correction of the insurance credit policy (deferral of payment of receivables from the recipients). The SME sector is particularly sensitive to the payment of receivables by its customers. Delayed payment from customers may disturb the cash flow. Recently, business-related press informs again and again about the fact that the SME sector is experiencing a deterioration in the timeliness of the receivables. Payment bottlenecks oppress more 
than half of SME sector entrepreneurs who have had overdue debts of at least 60 days and this is not strictly dependent on the market situation. The problem of these payment delays affects more than $80 \%$ of entrepreneurs. Minimizing the risk of liquidity and insolvency is carried out by the constant monitoring of the payment of receivables, prompting for non-payment, checking the reliability of customers or vindication of debts. All information in this respect is collected by the accounting department and it should help to manage receivables and maintain financial liquidity by providing relevant data to the sales departments and the recovery (legal) department. Delayed receivables not paid within the time limit may cause bankruptcy of the entrepreneur, hence the necessity of special care for this type of risk and the ongoing monitoring of its level.

In addition to the information from financial statements, the entrepreneur should have additional information on at least: disturbances in the management of receivables, stocks, cash, maturities of liabilities, structure and size of commitments, expected capital requirements. The entrepreneur should also have information about the way the liquidity risk is arising, the methods of its valuation and how it is managed in his/her company.

Of course, the SME sector to be protected from a delayed payment can use factoring, since lack of liquidity disrupts all processes occurring in the enterprise, slows down investment and development, worsens relations with counterparties, not to mention the fact that it is the most common cause of bankruptcy.

The research of many institutions shows that this type of security is used by a small number of entities in the SME sector (up to 3\%), but they also do not verify the credibility of new counterparties and, while trying to prevent the lack of liquidity, apply inadequately selected financial tools, thus increasing debt and incurring additional extra costs. Many of them cannot react appropriately to incoming payment problems.

Another way of minimizing the risk are reserves which an entity creates to protect itself against the risk of business activity. In addition, reserves are a financial policy tool used to create the desired entity image in the financial statements. The condition for the creation of reserves is the occurrence of an event that will oblige the entity to fulfill its obligations in the future, but provided that there is a possibility of a reliable estimation of losses or costs that will be required to be incurred 
so that the entity could meet its responsibilities. The procedure for the recognition of reserves in the accounting system is complicated, as it is necessary to assess the situation in the light of the necessity or the possibility of creating them, and more importantly, to determine the correct amount. The difficulty of estimation is related to the distance of the expected event. The reserves for the protection of an entity against a risk cannot be made at an excessively high amount, as this leads to an excessive burden on the financial result.

\section{RESEARCH RESULTS}

Research on the use of accounting in risk management. Small and medium-sized enterprises have a low use of risk management capabilities, particularly by using accounting. Most often, to optimize costs, they surrender running records and settlements to accountancy offices, which not only make records, accounts, but also provide consultancy and analysis of business finance. Minimization of tax risks, incorrect records, inadequate program, settlements with the Polish Social Insurance Institution (ZUS) etc. is carried out by transferring the tax risk to a specialized external entity. Most frequently, enterprises in the SME sector maintain simplified records in the form of a tax revenue and expenditure book, hence accounting is not used to manage the risk of receivables, erroneous decisions, liquidity or abuse.

The research carried out during the economic abuse survey in a group 100 entities of the SME sector has shown that there is no internal control system in the micro and small entities of nearly $83 \%$ of the surveyed and about the internal audit heard only $29 \%$, while $74 \%$ identified it with the audit of financial statements and claims that it does not concern them. Among the surveyed (most frequently entity owners), the overwhelming majority (76\%) do not link the possibility of using accounting in risk management. Importantly, just over half of the surveyed have no knowledge of risk management. Most commonly, those having a master's degree in Management Sciences have minimum knowledge of the risks and their management. Typically, they enumerate: risk of losing receivables and liquidity, errors in tax settlements, random risks (fire, flood, theft), and less often - market risk, credit, competition. 
Owners of micro-enterprises (36 persons: including 15 persons $50+$ ) do not believe that they should be involved in risk management, because their businesses are small so there is no risk there. SME managers are aware of risks in the economy (almost 60\% are trying to identify them). Among the surveyed, about $42 \%$ claim that their entity is well prepared to manage the risk from an organizational, but also substantive perspective. However, the subsequent analysis of the study shows that this assessment may differ from the actual state, since some of managers reduce the risk to a few of the most important ones, ignoring others that sporadically occur in the SME sector. The low level of awareness of risks, the possibility of prevention and risk avoidance are confirmed by the responses of the survey. Taking preventive measures confirmed $45 \%$ of the respondents (they stated insurance policy as a basic requirement), indicating that the prevention of most common risks is often imposed by legal regulations. Just over $40 \%$ take measures to avoid the risk or transfer it, and these are frequent checks on assets (here they often apply insurance cover for property), transfer of records and tax settlements to the accountancy office, and less frequently - factoring or recovery services. Unfortunately, this confirms the previously mentioned low level of risk awareness in these small entities.

When asked whether they are using professional risk management services, a positive answer gave only $22 \%$ of respondents. None of the respondents used services of auditors in this field. Sometimes they ask their accountancy offices for advice on the risk of liquidity, tax and business financing. Management in these entities is therefore vitiated by a number of errors and becomes inefficient. When asked about the possibility of using full records, although it is not obligatory, the entrepreneurs argued that these were additional unnecessary costs, and that the simplified records were sufficient to run their company.

Interviews in several accountancy offices (the study was carried out in 15 offices in the Masovian voivodeship and in 15 offices in the Podkarpackie voivodeship in August 2018; not all entities agreed to give an interview, hence the article contains only final conclusions) on the use of accounting in risk management by micro and small entities show that entrepreneurs are more interested in tax optimization issues than in risk minimizing. They react most frequently to risk-related problems and, according to the offices, they do not take preventive measures apart from the necessary business insurance policies. They 
do not prevent risk factors because some of them are unaware of their existence. The proposal for ancillary services, in the form of one of the audit types, or assistance in implementing professional internal control is usually rejected by the managers. When asked whether the offices propose the use of full business records (even the simplified form) which can help control the business, employees of the offices argued that some owners were trying for a long time in the past to remain on simplified records, sometimes even under-cutting revenues or transferring them as far as possible to a new fiscal period. The last question referred to the services offered by the offices, regarding assistance in developing a risk management strategy. SMEs are not interested in such services, not to mention the involvement of professional risk managers.

\section{CONCLUSIONS}

Nearly $95 \%$ of SMEs are micro-enterprises employing up to 9 people and the managing body is the entity owner. The owners of such entities consider that, with such a small scale of activity, they do not need to manage risks, moreover, they do not keep full records of their activities, and this hinders the identification, analysis and control of risks in their company.

The SME sector requires adequate risk management support. The continuous cost reduction in such a competitive environment makes small economic entities limit the prevention, retention or use of insurance policies.

Studies show that the entrepreneurs of small and medium-sized enterprises sector almost do not benefit from services of professional advisors in the risk management. This can confirm concerns about inefficient, incorrect risk management in this sector. The lack of internal control or the introduction of an independent audit causes an inability to react appropriately to the occurrence of the risk symptoms.

Only a few small enterprises are required by law to keep accounting books. Other small businesses have the option of using full accounting in a simplified manner, but very few companies decide to choose this type of solution. The reasons for this situation can be connected with limited knowledge of finance, accounting and management of managers in the SME sector. This means lack of readiness for the use of financial information, and thus lack of information needs on 
the financial situation of the company. And yet, according to Izabela Witczak (2017, p. 319):

Compliance with the accounting principles and the proper policy of the company increases the likelihood of the enterprise's objectives being met and provides a shield against the negative risks the enterprise is exposed.

Also, we should not belittle the role of the correctness, accuracy and transparency of financial reports when dealing with contractors, since they constitute the basis for economic security, and thereby help minimize the risk (Klamut, 2018, p. 67). The unwillingness to apply full bookkeeping is also aggravated by the higher costs associated with its handling (compared to simplified tax records).

On the basis of the above, it appears appropriate to develop suitable small-scale means of risk identification (tools), with low costs of implementation and their current use, and also the application of minimized records of business activity. It is difficult, but not impossible. It is worthwhile to carry out deeper research in this sector as up to 99.9\% of all companies belong to that group, and the Polish young entrepreneurs are eager to use new useful tools that will enable them to succeed, and to develop their business activities.

In summary, in addition to acquiring the appropriate risk minimization tools as well as the financial information required from the accounting system, it would be necessary to implement appropriate education systems for entrepreneurs and the people running their books on the use of accounting in risk management. This can be done by organizations related to the functioning of the SME sector and, inter alia, PARP. With EU funds, they should organize free risk management training sessions for SME entrepreneurs.

In addition, it can surely be concluded that, in the entities running full record of risk management, ERM contributes to the improvement of accounting quality (Cohen et al., 2014; COSO, 2014).

\section{REFERENCES}

Brustbauer, J. (2014). Enterprise risk management in SMEs: Towards a structural model. International Small Business Journal [in press].

Burzym, E. (1980). Rachunkowość przedsiębiorstwa i instytucji. Warszawa: PWE. 
Burzym, E. (1993). Przesłanki i perspektywy standaryzacji i międzynarodowej harmonizacji rachunkowości. Zeszyty Teoretyczne Rady Naukowej, 23, 7-9.

Cohen, J., Krishnamoorthy, G. \& Wright, A. (2014). Enterprise Risk Management and the Financial Reporting Process: The Experiences of Audit Committee Members, CFOs, and External Auditors, https://onlinelibrary.wiley.com/doi/ abs/10.1111/1911-3846.12294 (accessed: 7th Oct 2018).

COSO (2014). Enterprise Risk Management - Integrated Framework: Executive Summary. Committee of Sponsoring Organizations of the Treadway Commission.

Financial Reporting of Risk. Proposals for a Statement of Business Risk (1997). London: Institute of Chartered Accountants in England and Wales.

Gajda, D. (2014). Rola ubezpieczeń majątkowych w zarządzaniu ryzykiem małych i średnich przedsiębiorstw. Finanse, Rynki Finansowe, Ubezpieczenia, 67, $211-219$.

Karmańska, A. (red.) (2008). Ryzyko w rachunkowości. Warszawa: Difin.

Key Risks for Small and Medium Enterprises (SMEs) in 2015 (2015). Global survey report. Group Marketing \& Communications Insights Zurich.

Kim, Y. \& Vonortas, N.S. (2014). Managing risk in the formative years: Evidence from young enterprises in Europe. Technovation, 34(8), 454-465.

Klamut, E. (2018). Internal audit took for minimizing the risk of fraud. Financial Internet Quarterly "e-Finanse”, 14(1), 49-68.

Kokot-Stępień, P. (2015). Identyfikacja ryzyka jako kluczowy element procesu zarządzania ryzykiem w przedsiębiorstwie. Finanse, Rynki Finansowe, Ubezpieczenia, 74(1), 533-544.

Korombel, A. (2011). Kluczowe ryzyka i ich klasyfikacje w praktyce mikro i małych przedsiębiorstw. In: J. Buko (ed.). Strategie zarzadzania mikro, matymi i średnimi przedsiębiorstwami (pp. 229-242). Szczecin: Uniwersytet Szczeciński.

Lavia Lopez, O. \& Hiebl, M.R.W. (2014). Management accounting in small and medium-sized enterprises: Current knowledge and avenues for further research. Journal of Management Accounting Research [in press].

Marcelino-Sádaba, S. et al. (2014). Project risk management methodology for small firms. International Journal of Project Management, 32(2), 324-340.

Przywecki, M., Słabosz, J. \& Ziomko, R. (2013). Zarzqdzanie ryzykiem i ubezpieczeniami $w$ firmach $w$ Polsce. Raport AON Polska.

Słabosz, J. \& Ziomko, R. (2009). Zarzqdzanie ryzykiem i ubezpieczeniami w firmach $w$ Polsce. Raport AON Polska.

Witczak, I. (2017). Wybrane dylematy dotyczące rachunkowości w procesie zarządzania ryzykiem w firmie. In: J. Lichtarski (red.). Przedsiębiorczość i Zarzadzanie, 18(3/2), 311-325. 